\title{
Stocking density and production of a supplemented beef herd grazing yearlong on Mediterranean grassland
}

\author{
M. GUTMAN, Z. HOLZER, N.G. SELIGMAN, AND I. NOY-MEIR
}

\section{Abstract}

The possibility of attenuating the negative effects of high stocking rate (SR) on animal production by using inexpensive low energy supplements (mainly poultry litter) was examined in a herd of small, crossbred cows grazing yearlong on Mediterranean grassland. Herds of 15 to 25 cows were stocked at $0.50,0.67$, and 0.83 cows/ha in replicated blocks. Weaning weights and $A D G$ of calves were higher $(P<.001)$ at the low $S R$, but there were no differences between the moderate and heavy stocking treatments. Weaned weight per hectare as well as supplementary feed consumption were highest at the high SR, but differences between the low and moderate stocking treatments were not significant. Conception rates fluctuated between years and declined at the heavy SR, only to recover dramatically in the last year of the experiment. Weaning rates were variable both within and between SR's from year to year, but overall 5-year SR means were not significantly different.

It is concluded that on the seasonal Mediterranean grassland typical of eastern Galilee where quality of dry summer pasture is low, supplementation based mainly on poultry litter and straw can buffer some of the effects of high stocking rates on animal production but cannot ensure consistently high productive performance even at low SR.

Key Words: poultry litter, feed supplementation, weaning rate, weaning weight, ADG, stocking rate, beef cattle

Mediterranean grassland, like all strongly seasonal pastures, is subject to severe intra-annual fluctuations in forage quality and availability (Gutman and Seligman 1979, Seligman and Gutman 1979). This need not necessarily be serious where animal density is low and the vegetation is sufficiently diverse nutritionally to enable the animals to select a relatively nutritious diet all year round (Morris and Sanchez, cited by Holzer et al. 1986). As animal density increases, production per animal tends to decrease even though production per unit area can increase (McMeekan 1959; Hart 1972, 1978; Jones and Sandland 1974; Connolly 1976).

Supplementary feeding of the herd serves to counter deficiency in the quality and/or availability of pasture (Wagnon et al. 1942, Ward 1968, Preston and Willis 1974, Allden 1981, Heitschmidt et al. 1982). Where quality feed is expensive in relation to the animal product, supplementation, if feasible at all, must be based on locally available, inexpensive, generally low quality feedstuffs. The latter are usually crop residues like straw and cotton gin trash (Coombe 1981) or waste products like citrus peel and poultry litter (Bhattacharya and Fontenot 1966, Fontenot et al. 1971, Holzer and Levy 1976, Tagari et al. 1976). In such cases, the supplementary feed can correct nutrient deficiency to a limited extent only; this can become increasingly serious as stocking density increases.

\footnotetext{
Range scientists (M.G., N.G.S.), Department of Natural Resources, Agricultura Research Organization, Bet Dagan; animal scientist (Z.H.), Department of Beef Cattle, ARO, Newe Ya'ar; professor (I.N.-M), Department of Botany, Hebrew University of Jerusalem, Jerusalem, Israel.

The authors wish to thank Mr. Zadok Cohen, manager of the Karei Deshe Experimental Range, Messrs. Nir Dor-Sinai and Kassem Ugbi, respectively, manager and chief stockman of the beef herd for their active cooperation in the carrying out of this experiment; and Mrs. Hagit Baram, who was responsible for the data processing.

Contribution No. 2134-E, 1987 series, from the Agricultural Research Organization, Bet Dagan, Israel.

Manuscript accepted 22 January 1990.
}

The present paper constitutes a report on a grazing trial that was set up to investigate the effect of stocking rate (SR) on supplementary feed consumption and liveweight production of a beef herd grazing a Mediterranean grassland yearlong. The supplementary feed used was mainly poultry litter which was freely available from the beginning of summer until the onset of the subsequent green season.

\section{Materials and Methods}

\section{Study Area}

The trial was conducted at the Karei Deshe Experimental Range in the eastern Galilee region of Israel, situated near the confluence of the Jordan River and Lake Kinneret (Sea of Galilee), latitude $32^{\circ} 55 \mathrm{~N}$, longitude $35^{\circ} 35^{\prime} \mathrm{E}$, altitude $150 \mathrm{~m}$. The topography is hilly, with slopes generally less than $10 \%$. The soils are brown basaltic protogrumosols of variable depth, but seldom deeper than $60 \mathrm{~cm}$, and with a rock cover of approximately $30 \%$ (Gutman and Seligman 1979). The vegetation is a hemicryptophytic batha (Zohary 1972) dominated by Hordeum bulbosum L., Echinops spp., Psoralea bituminosa L., and many annual species, some of which are palatable pasture plants (Avena sterilis L., Bromus spp., Trifolium spp., Medicago spp., and many others) while others are palatable for only short periods during the early vegetative phase (e.g., Scolymus maculatus L., Brassica nigra (L.) Koch., Echium judaeum Lacaita).

Six paddocks were available for the trial, each 25.5 to 33 ha in size and fenced so as to include equivalent proportions of the different range habitats in each paddock.

\section{Treatments}

Three stocking rates were imposed on the range: $0.50,0.67$, and 0.83 cows per hectare, designated respectively as low $(L)$, moderate $(\mathrm{M})$, and high (H). Each SR was replicated twice in a randomized block design. Cows with calf were introduced into the experiment on 3 January 1978 and maintained in the paddocks until the end of the experiment on 19 July 1982 . Cows that were removed from the herds for various reasons, (infertility or no conception during 2 consecutive years, disease or death) were replaced, usually after weaning, by pregnant cows. The earliest calves in any season were weaned about 1 month earlier than the later calves.

Throughout the dry and transitional seasons, poultry litter (crude protein $=16$ to $28 \% ;$ TDN $=36$ to $46 \% ;$ ME concentration $=$ 1.31 to $1.67 \mathrm{Mcal} / \mathrm{kg} \mathrm{DM}$; ash $=18 \%$ to $36 \%$; DM content $=83$ to $89 \%$ ) was freely available in special troughs and a continuous record of consumption was kept. Barley grain was added to the poultry litter at a rate of $20 \%$ during later summer just after the onset of the calving season, when approx. $30 \%$ of the cows in the herd calved. Straw was supplied in limited quantities whenever the amount of residual dry litter in the pasture was limiting intake severely (generally less than $500 \mathrm{~kg} \mathrm{DM} / \mathrm{ha}$ ). This occurred in the heavily stocked paddocks around September-October, and in the moderately grazed treatment after the first rains in November and December. In the lightly stocked paddocks, straw was given in small amounts only in the first year of the experiment. In the fifth 
year, 1982, the experiment was terminated at the beginning of summer before supplementary feed was given. Consequently, supplementary feed data are available for only 4 years. The time of feeding, breeding, calving, and weaning is illustated in Fig. 1.

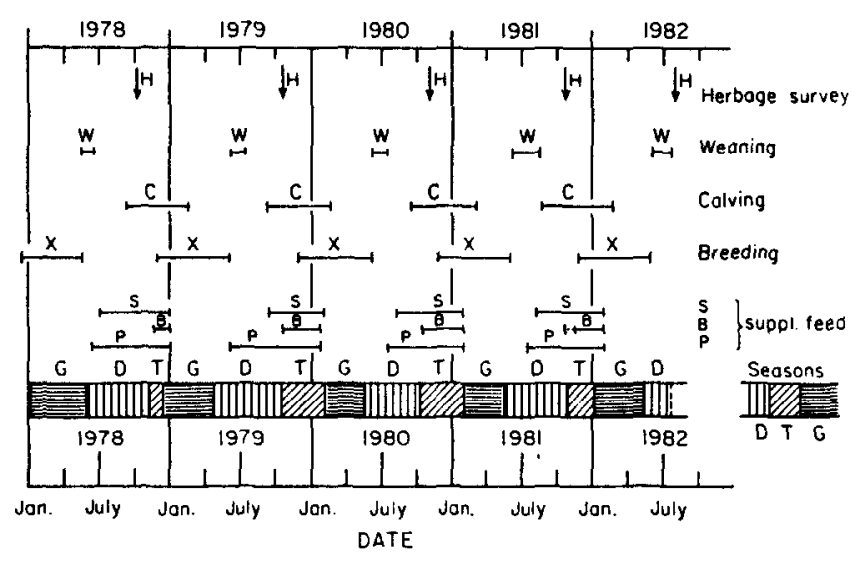

Fig. 1. Duration of dry (D), transitional (T) and green (G) pasture seasons and timing of supplementary feeding (poultry litter, P; barley grain, B; staw, S), breeding (X), calving (C), weaning (W) and end-of-season residual herbage survey (H) during the experiment, 1978-1982.

\section{Animals}

The cows were crosses and backcrosses between local Arab (Balady) cows and Hereford, Simmenthal, and Brahman bulls. Age distribution and breed composition were typical of many commercial herds in the region. Cows were small and weighed on the average $340 \mathrm{~kg}$. They were grouped into herds composed of 15 to 25 cows each and with uniform age distribution between herds. The cows in the lightly grazed treatments were initially approximately $12 \mathrm{~kg}$ heavier than those in the other treatments (Fig. 2).

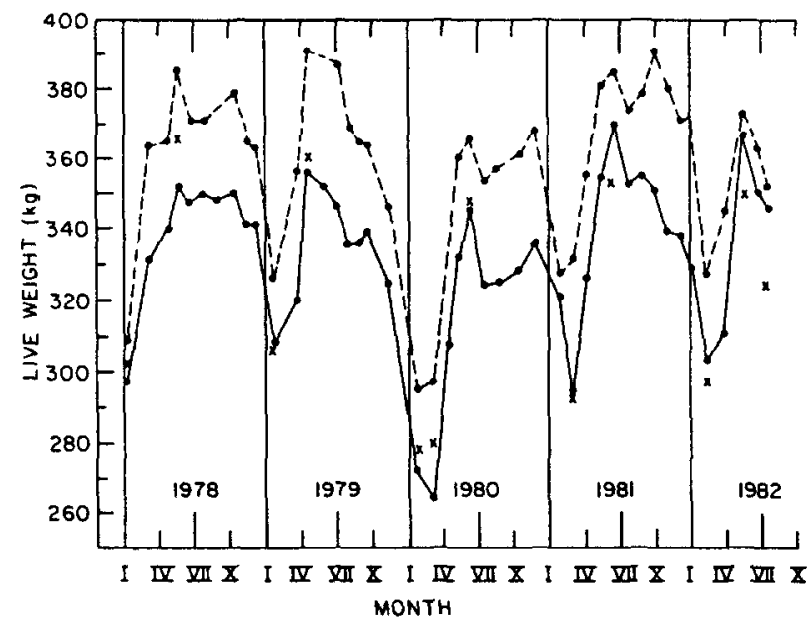

Fig. 2. Changes in body-weight at different stocking rates of cows that were in the experiment for the full 5-year period.

Stocking rates: - - - low; $\times$ moderate; - - - - high.

Bulls were grade Simmental and were with the herds between 15 November and the end of May, after which the calves were weaned, generally between June and August (Fig. 1). Pregnancy tests (by rectal palpation) were conducted after the last weaning and about 3 months after the bulls were removed from the herds. Animals were weighed every 1 to 2 months after $18 \mathrm{~h}$ withdrawal of access to water and feed.

\section{Residual End-of-season Herbage}

Each year a survey of residual herbage was conducted towards the end of the summer grazing season and at the beginning of the transitional season (Fig. 1). Dry herbage weight was determined by double sampling based on visual estimates made on approx. $30025 \times 25-\mathrm{cm}$ quadrats per paddock spaced at 10 double paces along permanent transects. Every tenth quadrat was also clipped, dried, and weighed for calibration of the estimates (Tadmor et al. 1975).

\section{Weather}

The rainy season in the region begins in October-November and ends in April-May. Mean rainfall is approximately $550 \mathrm{~mm}$ but vegetative growth is strongly influenced by rainfall distribution and intensity. Total annual precipitation during the experiment was $599,327,752,727$, and $358 \mathrm{~mm}$ for the $1977 / 78$ through 1981/82 seasons, respectively. There was no correlation between total amount of rainfall and pasture biomass production. The $1979 / 80$ and 1980/81 winters were very cold and wet, calving conditions were difficult and mortality was relatively high. The effective green season between range readiness and the beginning of the dry season varied, as indicated in Figure 1.

\section{Statistical Analysis}

Analysis of variance based on paddock means was calculated with the SAS (1985) GLM procedure. The sources of variance that were analyzed included SR, year, and the interaction between them. Standard errors of the SR means were calculated from the error sum of squares; significant differences $(P<0.05)$ between treatment means were determined by Duncan's multiple range test.

\section{Results and Discussion}

\section{Changes in Live-weight of Cows}

The body-weight of cows, uncorrected for fill or pregnancy, fluctuated over the experimental period, peaking at the beginning of the dry season (April to July) and dropping to low values after calving between October and April (Fig. 2). After the early summer peak there was a secondary peak between October and January, as pregnancy advanced towards parturition. Over the whole experimental period, the cows in the lightly stocked treatment were heavier than those in the heavily stocked treatment, and tended to recover more rapidly after the post-calving slump. The weights of cows maintained at the moderate SR were similar to those at the heavy SR. The curves in Figure 2 were derived from cows that were present from the beginning to the end of the experiment (approximately $65 \%$ of the data set). Inclusion of the replacement cows did not change the pattern significantly. The mean weights of all the cows at weaning were significantly different only at the low SR (Table 1).

\section{Weaning Weight and ADG}

Over the 5 years of the experiment, weaning weights decreased from year to year at the low, and more severely at the moderate SR (Fig. 3e). At the high SR this tendency was even stronger in the first 3 years but subsequently weaning weights started to increase again. Overall mean weaning weight was highest at the low SR, but not significantly different between the moderate and high SR's (Table 1). Weaning weight is a function of ADG, age until weaning, and birth weight. ADG was significantly influenced by many factors, including cow weight and SR (Table 2). Cow weight, in turn, was related, inter alia, to age of cow and SR; and cow age was slightly but significantly related to $S R$. The relation between cow weight and ADG can also be discerned by comparing Figures 2 and 3d. It appears that the animals at the highest SR were in better condition throughout the experiment and recovered more rapidly after the post-calving slump. The better condition was attained mainly during the green season (Fig. 2) and not by greater supplementary feed consumption (Fig. 3b). There was a fairly close relationship ( $r=$ $0.66, P<.001$ ) between residual end-of-season herbage and ADG 
Table 1. Mean and standard error of variables related to cow and calf weights, reproductive performance, supplementary feeding and residual end-of-season herbage dry matter at 3 stocking rates and over 5 years, 1978-1982.

\begin{tabular}{|c|c|c|c|c|}
\hline \multirow[b]{2}{*}{ Variable } & \multicolumn{3}{|c|}{ Stocking rate } & \multirow{2}{*}{ SEM $^{2}$} \\
\hline & Low & Moderate & High & \\
\hline $\begin{array}{l}\text { Animal density, cows/ha } \\
\text { Herd size, cows/treatment } \\
\text { Cow live-weight at weaning, } k g\end{array}$ & $\begin{array}{l}0.50 \\
32 \\
366 \mathrm{a}\end{array}$ & $\begin{array}{l}0.67 \\
36 \\
339 \mathrm{~b}\end{array}$ & $\begin{array}{l}0.83 \\
44 \\
341 b\end{array}$ & $\begin{array}{l}- \\
\overline{ \pm} 5.1\end{array}$ \\
\hline $\begin{array}{l}\text { Calf } \mathrm{ADG}^{3}, \mathrm{~kg} / \mathrm{d} \\
\text { Calf age at weaning, } \mathrm{d} \\
\text { Calf weight at weaning, } \mathrm{kg} \\
\text { Calf live-weight production, } \mathrm{kg} / \mathrm{cow} \\
\text { Calf live-weight production } 3, \mathrm{~kg} / \mathrm{ha}\end{array}$ & $\begin{array}{l}0.76 \mathrm{a} \\
223 \\
200 \mathrm{a} \\
161 \\
73 \mathrm{~b}\end{array}$ & $\begin{array}{l}0.68 \mathrm{~b} \\
214 \\
178 \mathrm{~b} \\
145 \\
82 \mathrm{~b}\end{array}$ & $\begin{array}{l}0.68 \mathrm{~b} \\
229 \\
186 \mathrm{~b} \\
145 \\
104 \mathrm{a}\end{array}$ & $\begin{array}{l} \pm 0.016 \\
\pm 5.6 \\
\pm 4.3 \\
\pm 8.4 \\
\pm 6.3\end{array}$ \\
\hline $\begin{array}{l}\text { Conception rate } 4, \% \\
\text { Calving rate }, \% \\
\text { Weaning rate }, \%\end{array}$ & $\begin{array}{l}78 \\
85 \\
80\end{array}$ & $\begin{array}{l}74 \\
84 \\
81\end{array}$ & $\begin{array}{l}79 \\
81 \\
78\end{array}$ & $\begin{array}{l} \pm 5.7 \\
\pm 3.8 \\
\pm 4.4\end{array}$ \\
\hline $\begin{array}{l}\text { Supplemental ME, } 10^{3} \mathrm{Mcal} / \mathrm{cow} / \mathrm{yr} \\
\text { Supplemental ME, } 10^{3} \mathrm{Mcal} / \mathrm{ha} \\
\text { Residual herbage DM, tonne/ha }\end{array}$ & $\begin{array}{l}1.67 \mathrm{~b} \\
0.86 \mathrm{c} \\
1.23 \mathrm{a}\end{array}$ & $\begin{array}{l}1.67 \mathrm{~b} \\
1.10 \mathrm{~b} \\
0.82 \mathrm{~b}\end{array}$ & $\begin{array}{l}2.41 \mathrm{a} \\
2.08 \mathrm{a} \\
0.66 \mathrm{c}\end{array}$ & $\begin{array}{l} \pm 0.141 \\
\pm 0.028 \\
\pm 0.046\end{array}$ \\
\hline
\end{tabular}

IWithin rows, data followed by different letter are significantly different $(P<0.05)$.

2Standard error of the mean.

${ }^{3}$ Data in 1978 corrected for initial weight of calves on entry into experimental paddocks.

${ }^{4}$ Calving and weaning rates based on all cows, including replacements.

Conception based on cows that were in the herd during the previous breeding season.
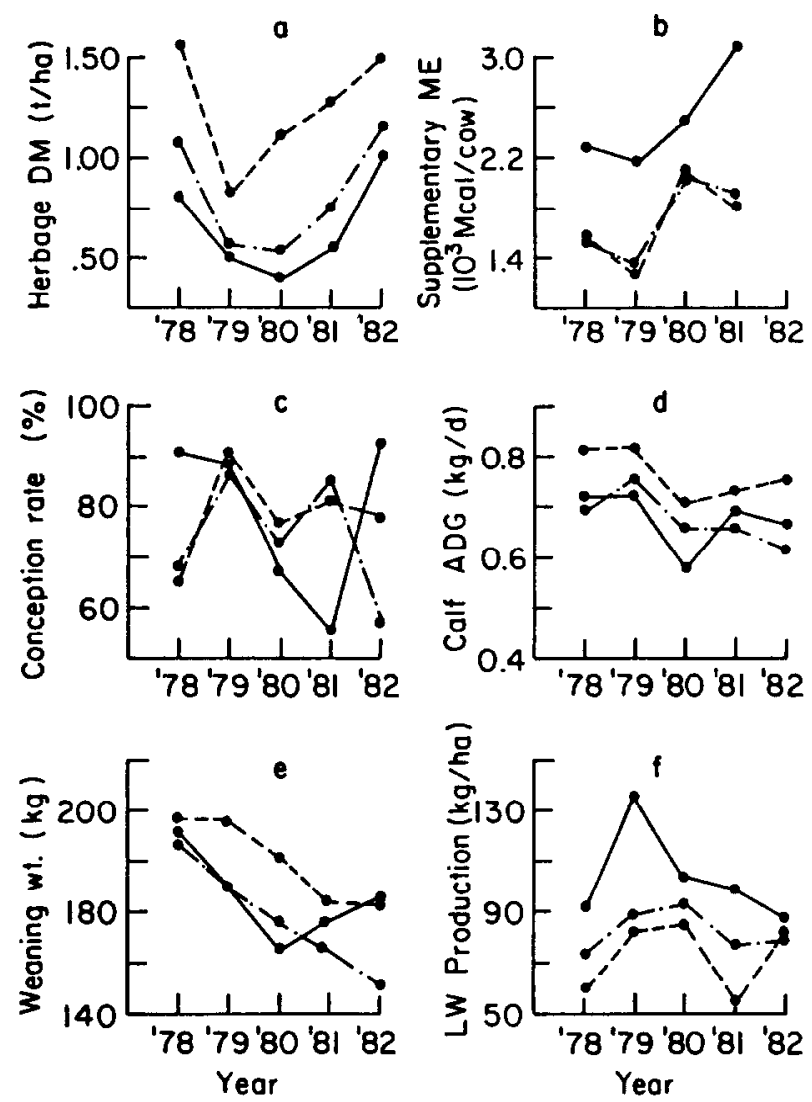

Fig. 3. Year-to-year variation in residual end-of-season herbage dry matter (DM) (a), metabolic energy consumed as supplementary feed (b), conception rate (c), calf average daily gain (ADG) (d), calf weaning weight (e), calf liveweight production per unit area of rangeland ( $)$, at 3 stocking rates: - - low; - $\bullet-\bullet$ moderate, -

in the following green season (Fig. 4). However, in this case, the end-of-season residual herbage is probably less important per se than as an indicator of green season feed availability and consequent cow condition at calving.

Calf age at weaning (roughly equivalent to month of birth in

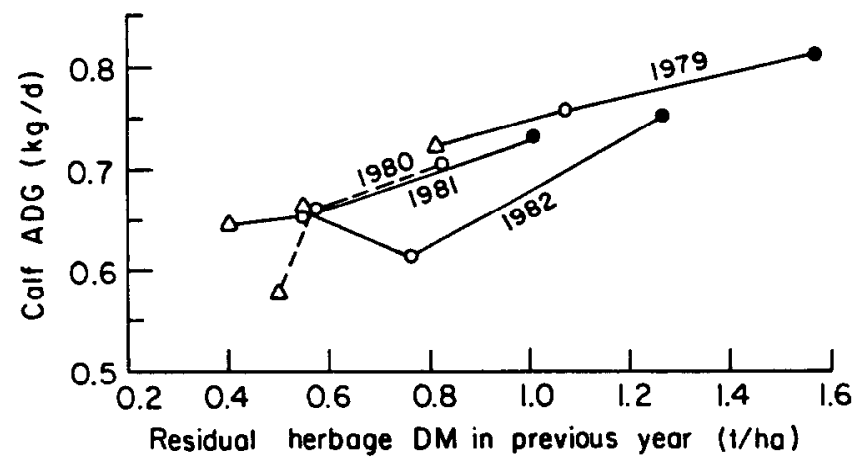

Fig. 4. Relationship between residual end-of-season herbage dry matter (DM) and calf average daily gain (ADG) at different stocking rates (SR) in each year of the experiment (low $S R$, solid circles; moderate $S R$, open circles; high SR, triangles).

Table 2. Decomposition of performance parameter sums of squares (SS) into constituent factors ( $\%$ of total SS)'.

\begin{tabular}{llclll}
\hline \hline \multicolumn{5}{c}{ Parameters } \\
\hline & $\begin{array}{l}\text { Weaning } \\
\text { weight }\end{array}$ & $\begin{array}{c}\text { Month of ADG } \\
\text { birth }\end{array}$ & $\begin{array}{l}\text { Cow } \\
\text { weight }\end{array}$ & $\begin{array}{l}\text { Cow } \\
\text { age }\end{array}$ \\
\hline $\mathrm{R}^{2}$ & 0.922 & 0.305 & 0.365 & 0.227 & 0.121 \\
CV $(\%)$ & 5.6 & 14.9 & 12.1 & 13.9 & 32.0 \\
\hline Source & & & & & \\
\hline Month of birth & $57.2^{* * *}$ & - & $3.3^{*}$ & - & - \\
ADG & $31.4^{* * *}$ & - & - & - & - \\
Cow wt & 0.1 & - & $11.3^{* * *}$ & - & - \\
Age of cow & 0.1 & 0.3 & $3.1^{*}$ & $7.5^{*}$ & - \\
Stocking rate & 0.0 & 1.4 & $3.8^{*}$ & $4.9^{*}$ & $1.4^{*}$ \\
Year & $3.0^{*}$ & $26.6^{* * *}$ & $10.1^{* * *}$ & 8.5 & $9.1^{*}$ \\
SR $\times$ YR & $0.5^{*}$ & 1.4 & $4.5^{*}$ & $7.6^{*}$ & 1.4 \\
Block & 0.0 & 0.9 & 0.4 & 0.4 & 0.2 \\
Residual & 7.8 & 69.5 & 63.5 & 77.3 & 87.9 \\
\hline
\end{tabular}

$* * *<.001$

- P<.05

${ }^{1}$ Total of all constituents SS $(\%)=100 \times R^{2}$. Total number of calves $=446$

${ }^{2}$ At weaning. 
Table 2 , because weaning occurred over a relatively short period, as shown in Figure 1) was not significantly related to SR (Table 1). The relationship is more complex as can be seen in Figure 5. The generally lower weaning age at the moderate SR is the result of

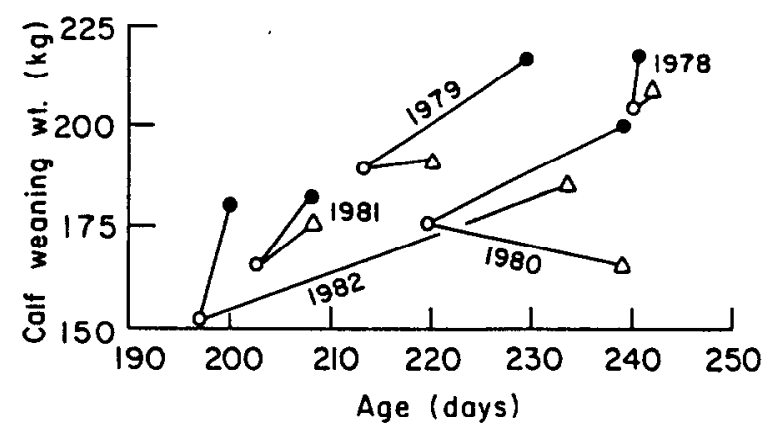

Fig. 5. Relationship between age and weight of calf at weaning, at different stocking rates (SR) in each year of the experiment (low SR, solid circles; moderate SR, open circles; high SR, triangles).

consistently later calving. This could be a consequence of the relatively poorer condition of the cows at this $S R$ towards the end of the experiment (Fig. 2).

While ADG at the low SR fluctuated within relatively narrow bounds, at the moderate rate it decreased consistently over the last 4 years. At the heavy SR, ADG declined even more during the first 3 years but subsequently recovered (Fig. 3d). At the high SR, compensatory responses of the animal and the vegetation tended to even out differences between treatments.

\section{Weaning and Conception Rates}

These were calculated as calves weaned to cows (including replacement cows) currently in the herd in any given year. The rates fluctuated between $56 \%$ and $88 \%$ after the first year but the 5-year means between treatments were very similar and varied between $78 \%$ and $81 \%$ (Table 2). The means for the 4 years between the second and fifth year were approximately $5 \%$ lower. The weaning rates of cows that entered the experiment in the first year were similar to the mean weaning rates, because the replacement rate was relatively low: approximately $10 \%$ per year during the 4 years between 1979 and 1982.

The fluctuations in conception rates between years were large at all SR and the pattern varied widely (Fig. 3c). It appeared to be related to compensatory responses within each herd rather than to direct SR effects. The 4-year decline at the high SR and the dramatic recovery in the last year are particularly noteworthy. The means for the 5 years were not significantly different (Table 1), mainly because of the strong year $\times$ SR interaction. Reproduction is, as a rule, strongly influenced by the condition of the animals at calving and soon after (Wiltbank et al. 1962, 1964; Dunn and Kaltenbach 1980; Richards et al. 1986). In this experiment parturition took place during the difficult transitional season between the end of summer and the beginning of the green season (Fig. 1), when relatively small differences in pasture availability seemed to trigger long-term reproductive responses.

\section{Liveweight Production Per Cow}

Liveweight production per cow is a function of calf weaning weight and weaning rate. At the low SR it was considerably higher than in the other treatments (Table 1). Nevertheless, the difference was not significant, mainly because of an unusually low weaning rate in 1981.

\section{Liveweight Production Per Unit Area}

Despite the steep decline in animal performance at the high stocking rate (Fig. 3e), the liveweight production per hectare (Fig. 3f) was consistently and significantly higher than in the other treatments (Table 1). This, however, was attained at a greater cost in supplementary feed (Fig. 3b). The mean supplementary feed increment per unit liveweight increment per hectare between low and moderate SR was $24 \mathrm{Mcal} / \mathrm{kg}$ liveweight, and between moderate and heavy SR's, it was 37.1. Thus, the marginal efficiency of the supplementary feed utilization for liveweight production decreased as $\mathrm{SR}$ increased.

\section{Dry Herbage Mass at the End of Summer}

In the high SR treatments, the amount of dry herbage at the end of summer, just before the autumn rains, approached the residual level below which it was practically unavailable to the cows (Fig. 3a). At moderate SR this level was approached somewhat later while at the low SR the herbage levels were well above the ungrazable residual in all years. The high values in the first year are partly the result of the late start of the experiment. The high values in the last year (1982) are not comparable with previous years, because the experiment was terminated on 19 July 1982 and there were no cows in the paddocks until the survey of dry herbage in September of that year (Fig. 1).

\section{Feed Supplementation}

The partial recovery of animal performance at the high SR during the last 2 years of the study could have been related to heavier use of supplements (Fig. 3b). Over all the years, supplementation was heaviest at the highest SR, where end-of-summer dry herbage mass was depleted to very low levels of approximately $500 \mathrm{~kg} \mathrm{DM} /$ ha (Fig. 3a). There was no difference between the amounts of supplementary feed given per head at the low and moderate stocking rates despite large differences in end-of-summer dry herbage mass (Table 1). This pattern was more or less consistent from year to year (Fig. 6). At lower SR's, with more available

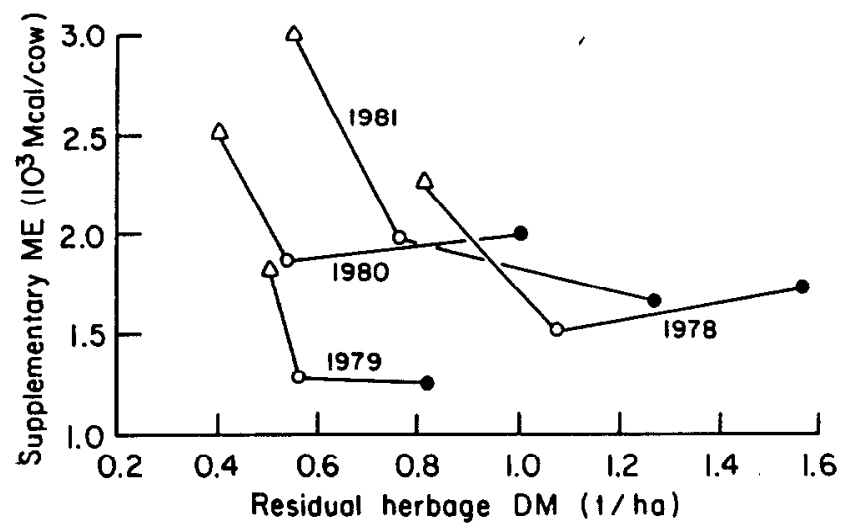

Fig. 6. Relationship between residual end-of-season herbage dry matter (DM) and metabolizable energy consumption as supplementary feed at 3 stocking rates (SR) in each year of the experiment (low SR, solid circles; moderate SR, open circles; high SR, triangles).

dry pasture, the poultry litter appeared to be consumed in relatively small amounts, possibly as an $\mathrm{N}$-supplement only, while at the higher SR it served also as a roughage supplement. However, amount of available dry herbage was not the only factor that determined supplement intake, as evidenced by the fact that even when residual end-of-season herbage DM was more than 700 $\mathrm{kg} / \mathrm{ha}$, supplementary feed intake increased considerably at the high SR while it remained relatively constant at the low and moderate SR's (Fig. 6). Differences in the quality of the dry pasture could account for this, but no supporting evidence is available. 


\section{Conclusion}

It appears that supplementation in summer with low quality feedstuffs like poultry litter buffered the effect of high SR on reproductive performance in comparison with low SR. However, even at the low SR, reproductive performance was only fair. It appears that the ME concentration of the supplements given in this experiment during the poor-quality-pasture period was too low to allow full expression of the reproductive potential of the cows.

Strong SR effects on ADG and on the weaning weight of calves were not translated into significant differences in mean weaned liveweight per cow in the herd, because of the overiding effect of reproductive performance. As a result, the direct effects of stocking rate under the conditions in this experiment were confined to supplementary feed consumption and liveweight production per unit area. This confirms the observation of McMeekan (1959) that stocking rate is "probably the most powerful weapon influencing efficiency (of animal production) on a per acre basis", even though the longer term effect on cow productivity is not so unequivocal.

\section{Literature Cited}

Allden, W.G. 1981. Energy and protein supplements for grazing livestock. In: F.H.W. Morley (ed.), Grazing animals. Vol. B1, World Animal Science Series, Elsevier Scientific Publ. Co., Amsterdam.

Bhattacharya, A.N., and J.P. Fontenot. 1966. Protein and energy value of peanut hulls, wood shavings and poultry litter. J. Anim. Sci. 25:367-371.

Connolly, J. 1976. Some comments on the shape of the gain stocking rate curve. J. Agr. Sci. (Camb.) 86:103-109.

Coombe, J.B. 1981. Utilization of low quality residues. In: F.H.W. Morley (ed.) Grazing animals. Vol. B1. World Animal Science Series, Elsevier Scientific Publ. Co., Amsterdam.

Dunn, T.G., and C.C. Kaltenbach. 1980. Nutrition and the postpartum interval of the ewe, sow and cow. J. Anim. Sci. 51 (Suppl. 2):29-39.

Fontenot, J.P., K.E. Webb, B.W. Harman, R.E. Tucker, and W.E.C. Moore. 1971. Studies on processing, nutritional value and palatability of broiler litter for ruminants. Proc. Int. Symp. on Livestock Wastes. ASAE Pub., Proc. 271-301-3-4, St. Joseph, Mich.

Gutman, M., and N.G. Seligman. 1979. Grazing management of Mediterranean foothill range in the upper Jordan river valley. J. Range Manage. 32:86-92.

Hart, R.H. 1972. Forage yield, stocking rate and beef gains on pasture. Herb. Abstr. 42:345-353.

Hart, R.H. 1978. Stocking rate theory and its application to grazing on rangelands. p. 547-550. In: D.N. Hyder (ed.), Proc. 1st Int. Rangeland Congr. Denver, Colo.
Heitschmidt, R.K., M.M. Kothmann, and W.J. Rawlins. 1982. Cow-calf response to stocking rates, grazing systems and winter supplementation at Texas Experimental Ranch. J. Range Manage. 35:204-210.

Holzer, Z., and D. Levy. 1976. Poultry litter as a protein supplement for beef cattle fed fibrous diets. Wild. Rev. Anim. Prod. 12:91-96.

Holzer, Z., J.G. Morris, M. Gutman, R. Benjamin, N.G. Seligman, and E. Bogin. 1986. Physiological criteria for improvement of production efficiency in beef cows subjected to nutritional and environmental "stress" due to fluctuating seasonal grazing conditions. Final rep., BARD project I-132-80, Bet Dagan, Israel.

Jones, R.T., and R.R. Sandland. 1974. The relation between animal gain and stocking rate: Derivations of the relations from results of grazing trials. J. Agr. Sci. (Camb.) 83:335-342.

McMeekan, C.P. 1959. Principles of animal production. Whitecombe and Tombs, Christchurch, New Zealand.

Preston, T.R., and M.B. Willis. 1974. Intensive beef production, 2nd ed. Pergamon Press, Oxfond.

Richards, M.W., J.C. Spitzer, and M.B. Warner. 1986. Effects of varying levels of postpartum nutrition and body condition at calving on subsequent reproductive performance in beef cattle. J. Anim. Sci. 62:300-306.

SAS. 1985. Users Guide: Statistics, Version 5. SAS Institute Inc., Cary, N.C.

Seligman, N.G., and M. Gutman. 1979. Cattle and vegetation responses to management of Mediterranean rangeland in Israel, pp.616-618. In:D.N. Hyder (ed.), Proc. 1st Int. Rangeland Congr., Denver, Colo.

Tadmor, N.H., A. Brieghet, I. Noy-Meir, R.W. Benjamin, and E. Eyal. 1975. An evaluation of the calibrated weight-estimate method for measuring production in annual vegetation. J. Range Manage. 28:65-69.

Tagari, H., D. Levy, Z. Holzer, and D. Ilan, 1976. Poultry litter for intensive beef production. Anim. Prod. 23:317-327.

Wagnon, K.A., H.R. Guilbert, and G.H. Hart. 1942. Experimental herd management in the San Joaquin Experimental Range, pp. 50-82. In: C.B. Hutchison and I. Kotok (eds.) Bull. No. 663, Univ. of California Agr. Exp. Sta., Berkeley, Calif.

Ward, H.K. 1968. Supplementation of beef cows grazing on veld. Rhodesian J. Agr. Res. 6:93-97.

Wiltbank, J.N., W.W. Rowden, J.E. Ingalls, K.E. Gregory, and R.M. Koch. 1962. Effect of energy level on reproductive phenomena of mature Hereford cows. J. Anim. Sci. 21:219-224.

Wiltbank, J.N., W.W. Rowden, J.E. Ingalls, and D.R. Zimmerman. 1964. Influence of post-partum energy level on reproductive performance of Hereford cows restricted in energy intake prior to calving. J. Anim. Sci. 23:1049-1055.

Zohary, M. 1972. Geobotanical foundations of the Middle East. Gustav Fischer Verlag, Stuttgart, and Swets and Zeitlinger, Amsterdam. 